\title{
Negritude e crioulização em Bruno de Menezes
}

\section{Négritude and criolization in Bruno de Menezes}

José Guilherme dos Santos Fernandes - Graduação em Letras pela Universidade Federal do Pará, mestrado em Lingüística e Teoria Literária pela Universidade Federal do Pará e doutorado em Letras pela Universidade Federal da Paraíba. Atualmente é professor adjunto da Universidade Federal do Pará. Email: mojuim@uol.com.br

\section{Resumo}

Este artigo tem por objetivo reconhecer a obra do poeta paraense Bruno de Menezes como antecipadora dos conceitos de negritude e crioulização, impressos em Aimé Cesaire e Edouard Glissant, conceitos que qualificam a modernidade do literato. Para tanto, serão analisados três poemas de Menezes, publicados no livro Batuque (1931), considerando-se o estilo e as condições sociais e históricas de produção. Conclusivamente, destaca-se que o não reconhecimento da poesia de Menezes, no cânone local e nacional, foi muito mais decorrente de fatores sociais do que em razão da qualidade de sua obra.

\begin{abstract}
This article aims to recognize the work of paraense poet Bruno de Menezes as forecasting of the concepts of blackness and creoulezation, these concepts created by Aimé Cesaire and Edouard Glissant, which qualify the modernity of this paraense poet. Then we will be analyze poems from Bruno de Menezes wrote in his book called Batuque (1931), considering the style and both social/ historical production conditions. Conclusively, we highlight that the non-recognition of poetry from Menezes, in local and national canon, it was much more social factors problems than the quality of his work.
\end{abstract}

\section{Palavras-chave}

Negritude. Cioulização. Bruno de Menezes. Amazônia. Cânone.

\section{Keywords}

Blackness. Creoulezation. Bruno de Menezes. Amazonia. Canon. 


\section{INTRODUÇÃO}

O sociólogo francês Roger Bastide (1898-1974) afirma, no ensaio $A$ incorporação da poesia africana à poesia brasileira (1940), que os positivistas brasileiros se preocuparam com o problema da incorporação da população afro-brasileira, recém-oriunda da escravidão, à comunidade nacional, mas que esse problema era de ordem puramente sociológica. No entanto, havia outro plano, nessa incorporação, de caráter mais ideológico: a incorporação da poesia negra à poesia brasileira. Aqui, a questão não se dirimia tão evidentemente, pois, mesmo havendo a participação efetiva do que Bastide intitula "os homens de cor", efetivamente o negro estava em segundo plano: "Mas o movimento partiu dos brancos, e, no conjunto, foi por eles dirigido. E mesmo os poetas de cor frequentemente se opuseram a isso, pois viam nessa valorização das coisas da África um obstáculo à sua assimilação" (BASTIDE, 1997, p. 17). Em meu entendimento, o maior obstáculo a essa assimilação da poesia reside na alteridade que se cria em relação ao negro na poesia, uma vez que falar sobre não é falar a partir, ou seja, estamos a um passo da criação de estereótipos e de exotismos, o que foi recorrente nos auspícios da poesia brasileira, a exemplo de parte da produção de Gregório de Matos, Basílio da Gama e Tomás Antonio Gonzaga, que apresentam ou o negro lascivo e corrupto, em teor satírico, ameaçando a integridade social por sua mestiçagem; ou o negro comportado e subserviente, em teor epopeico, na defesa dos portugueses; ou o negro selvagem e braçal, que deve estar distante do lirismo árcade, no trabalho nas minas. Em suma, o negro, nessas produções, é o passivo adjuvante, componente da paisagem ou o atuante vilão, que se insere para tensionar com o herói branco e português, seja nas batalhas ou na vida cotidiana, e, é claro, o necessário opositor para glorificar o fidalgo lusitano de além-mar. Havia, como ainda há, a necessidade de se estudar a produção literária poética no Brasil como uma história também dos "vencidos", a contra-pelo, no dizer benjaminiano.

Com toda razão, é em Castro Alves (1847-1871) que começa a se dissipar essa névoa ideológica do colonialismo, por mais que ainda hoje, no alvorecer de muitas manhãs, o nevoeiro se quede violento. De um primeiro momento idílico, em que a poesia castroalvina se debruça no elogio ao amor, na busca da comunhão entre as raças, a poética do baiano se transforma, paulatinamente, em poesia de teor social e revolucionária, para o momento: "Em vão procurarão unir-se os corações, as instituições sociais são bastante fortes para impedir a comunhão, o social é mais poderoso do que a boa vontade e que os sentimentos individuais; é preciso então voltar-se, daí para a frente, contra o social e fazer uma poesia revolucionária", nos diz Bastide (idem, p. 27). Daí o trânsito da poesia de Alves, que vai do lirismo amoroso primaveril à epopeia e drama dos conflitos veranos, a exemplos dos poemas "O 'adeus' de Teresa” (Espumas Flutuantes), "Vozes d'África” (Os escravos) e "Loucura divina” (A cachoeira de Paulo Afonso). Mas não há incoerência e sim transição, ainda mais se entendermos que a primavera é o primeiro verão (lat. primo vere, 'na primeira estação'), ou seja, em Castro Alves uma fase complementa a outra. Evidentemente outros poetas brasileiros virão, pós-Castro Alves, a compor o tema da poética afro-brasileira, como Jorge de Lima, Oswaldo de Andrade e Cassiano Ricardo. Mas Alves, provavelmente, inaugurou outro ponto de vista, outro lugar de enunciação, que não é mais do fidalgo lusitano decadente ou do mestiço que se quer embranquecer, pois o poeta baiano já compõe uma inteligentsia brasileira que tende a assumir o afro-brasileirismo, não apenas como a exaltação da raça, mas com um profundo teor de materialismo histórico, subterfugiamente compondo o drama do negro como o drama da raça humana, a partir do conflito de classes ou raças. É a partir desse ponto que gostaria de inserir a obra do escritor brasileiro, paraense e amazônida Bruno de Menezes (1893-1963), como um porta-voz "inconsciente" do afro-brasileirismo, ou melhor, do afro-amazonismo, que, mediante seu autodidatismo, construiu, como sua vida, com ardor e sacrifícios, uma poética que antecipa, na continuidade castroalvina, a crioulização de Edouard Glissant (MARTINICA, 1928), passando, evidentemente, pelo sentido e sentimento da negritude de Aimé Cesaire (Martinica, 1913-2008), além de ser um inaugurador do modernismo na Amazônia, pois sua obra Batuque, aqui em exegese, data de 1931, onde podemos ver, com toda nitidez, temas e formas que serão avant garde e complementação ao movimento modernista brasileiro de 1922. Isso tudo composto em Belém do Pará, uma cidade, àquele momento, tão distante cultural e geograficamente dos centros irradiadores do cânone nacional.

\section{CENÁRIO HISTÓRICO E SOCIAL DA PRODUÇÃO ARTÍSTICA DE BRUNO DE MENEZES}

Em primeiro lugar, é bom situar historicamente a produção do poeta paraense Bruno de Menezes, a constituição do movimento da Negritude e a construção do conceito de crioulização. Comecemos por situar Bruno de Menezes e sua poética nas condições sociais e históricas de produção. Nascido em fins do século XIX, a maturidade poética do autor, a partir dos anos 1920, vai ser coetânea da decadência da belle époque belenense, que se inicia por volta de 1910, com a crise da economia da borracha na região. Com isso, o fausto da cidade começa a dar visibilidade ao periférico; fausto este que se constituiu com as reformas urbanas do 
intendente Antonio Lemos, a partir de 1897. O espaço central da cidade passou por urbanização de vias e praças, empurrando-se para a periferia pantanosa da cidade os empobrecidos de toda monta, seja pelo poder econômico, seja pela origem étnico-racial, a exemplo do que aconteceu no Rio de Janeiro, com a Regeneração do prefeito Passos (1904).

Um desses bairros periféricos foi o Jurunas, local de nascimento do poeta e espaço de seus primeiros contatos com a vida periférica e popular, das baiúcas, das estivas e dos terreiros de bumbás e de santos, manifestações e práticas estas que tão bem são representadas em sua produção poética e ensaística. Essa condição periférica talvez tenha proporcionado a condição do entre-lugar de uma produção literária e cultural que irá focalizar outra cidade, não mais a Belém do copismo europeu da belle époque, mas a cidade da produção representativa de um movimento literário que instituiu definitivamente a modernidade na cidade, o que intitulo a Geração de 20 do modernismo paraense, ou geração do Peixe-Frito ${ }^{1}$, segundo Coelho (2005), capitaneada por Bruno de Menezes e Dalcídio Jurandir²: esse cenário da periferia, com suas manifestações culturais diversas e com suas personagens, está presente nos poemas do primeiro e no romanceiro do segundo, ambos os autores frutos e viventes desses espaços. Mas, entenda-se, é um novo foco a partir do periférico, mas que não oblitera os espaços centrais e de poder, é tão somente um outro lugar de enunciação que estatui uma nova forma de ver e de

Segundo Coelho, "a geração do peixe frito era 'constituída de rapazes paupérrimos que faziam heroicamente literatura lutando com todas as dificuldades econômicas possíveis', comentaria mais tarde Ruy Guilherme Barata. Rapazes como Dalcídio Jurandir, empregado público que se mudou para o interior do Estado, a fim de ganhar mais e, assim, pagar a prestação da máquina de escrever e que 'cavou dinheiro entre os amigos para pode enviar pelos correios o romance Chove nos campos de Cachoeira ao concurso Dom Casmurro, no Rio de Janeiro" (2005, p. 49). E por que geração peixe frito? Dalcídio Jurandir nos esclarece em prólogo do livro Chove nos campos de Cachoeira, por ocasião da premiação no concurso Dom Casmurro: “Ah! É notável a influência do peixe frito na literatura paraense! Peixe frito é o peixe vendido em postas nos tabuleiros do Ver-o-Peso ao lado do mercado em Belém. É comida para quem não deixa almoço comprado em casa. Ao chegar o meio-dia, o pobre se tem a felicidade de haver arranjado dois mil réis leva um embrulhinho envergonhado de peixe para casa. A vida literária do Pará tem se movimentado em torno do peixe-frito! Conheço profundamente esse drama" (apud COELHO, 2005, p. 48-49).

2 Dalcídio Jurandir (Ponta de Pedras, ilha de Marajó, 1909 - Rio de Janeiro, 1979) foi romancista, ensaísta, jornalista e funcionário público. É considerado um dos grandes romancistas da Amazônia, com uma obra marcada pelo realismo social e pela presença de diversos discursos atuantes na cultura e realidade amazônicas, em uma escritura que transita entre o fluxo de consciência e a narrativa oral. É autor de uma das maiores e mais representativas antologias sobre a região, o Ciclo do Extremo Norte, que se compõe de dez romances: Chove nos campos de Cacboeira (1941), Marajó (1947), Três casas e um rio (1958), Belém do Grão-Pará (1961), Passagem dos inocentes (1963), Primeira manbã (1968), Ponte do Galo (1971), Os babitantes (1976), Chão dos lobos (1976) e Ribanceira (1978). Em 1940 foi ganhador do concurso Dom Casmurro, patrocinado pela Editora Vecchi. dizer, somando a borda ao núcleo. Por isso afirma Rodrigues, em relação ao bairro do Jurunas, um “outro" lugar a partir do qual se pode observar a cidade de Belém:

Ao se constituir como um bairro da periferia de Belém, o Jurunas apresentava um relativo isolamento geográfico: embora localizado bastante próximo do centro comercial da cidade, não dispunha de infraestrutura mínima, de urbanização e transporte, que facilitasse a circulação dos moradores. Mas isso não implicou em isolamento sócio-cultural, pois os moradores circulavam incessantemente entre os espaços que ligavam o bairro ao centro da cidade, tanto nos dias comuns, freqüentando as lojas comerciais, a feira e o mercado do Ver-o-Peso, onde muitos trabalhavam, compravam ou vendiam alimentos e outros produtos ou serviços, quanto em dias de festa, especialmente nos fins de semana, quando freqüentavam missas e novenas, procissões e festas realizadas na igreja matriz ou nas paróquias que foram surgindo, participando de um amplo circuito de sociabilidade que ligava os diversos espaços da cidade que crescia continuamente (RODRIGUES, 2008, p. 76-77).

O que fica latente é que a experiência de vida do poeta, nesse bairro e no trânsito a outros bairros, foi a força motriz de sua produção e, diria, de sua opção intelectual, pois não só em Batuque o cenário periférico se torna crível, mas em seus ensaios antropológicos e folclóricos - Boi Bumbá (1958) e São Benedito da Praia (1959) - e em sua ficção narrativa - Maria Dagmar (1950) e Candunga (1954).

Mas se, por um lado, a experiência com o periférico acarretou um arsenal poético, tanto em Dalcídio como em Bruno, por outro lado causou uma certa desilusão, um certo pessimismo benjaminiano, talvez engendrado pelas aspirações comunistas do primeiro ou pelas preocupações solidárias e cooperativistas do segundo. Vejamos o que diz Dalcídio Jurandir em Carta datada de novembro de 1936 e publicada como abertura do ensaio literário de Menezes, intitulado $A$ margem da cuia pitinga (1937), acerca da obra de Jacques Flores³:

Fazer ironia em nosso meio é fazer uma dolorosa caricatura de si mesmo. O ódio é justo, é mais libertação. É preciso acusar e desmontar, praticamente, a farça e a miséria que negam a arte e a cultura. A província - e aqui não se entende, apenas, um sentido literário de província, mas a condição econômica - arriou sobre nós um peso enorme de tédios, ânsias mórbidas, burocracia, deformações irreparáveis... A cultura virou boemia (MENEZES, 1993: 380).

E Menezes, no ensaio acima aludido, dá ensejo ao que Jurandir disse: "Como têm a extraordinária coragem de proclamar Dalcídio Jurandir e Nuno Vieira, movimentam-se nas convulsões desse asphyxiante scenario os valores de nossa geração (...)" (idem, p.384-385). Asfixiante cenário, mas que não determina

Jacques Flores era o pseudônimo de Luiz Teixeira Gomes (Belém, 1898 - Belém, 1962). Foi jornalista, tipógrafo, funcionário público e poeta e prosador, participante ativo do Modernismo paraense, sendo integrante da geração de 20 deste movimento. 
a morte destes mártires poéticos, pelo contrário, dá munição para que continuem produzindo até o fim de suas vidas. O interessante é observar como em uma mesma época, sob as mesmas condições históricas e sociais, pensadores distantes geograficamente têm preocupações próximas, para não dizer solidárias. Veja o que nos diz Michael Löwy, no ensaio "A filosofia da história de Walter Benjamin”:

É porque percebe esse perigo catastrófico que Benjamin invoca o pessimismo em seu artigo de 1929 sobre o surrealismo, um pessimismo revolucionário que não tem nada a ver com a resignação fatalista e ainda menos com o Kulturpessimismus alemão, conservador, reacionário e pré-fascista (Carl Schmitt, Oswald Spengler, Moeller van der Bruck): o pessimismo aqui está a serviço da emancipação das classes oprimidas. Sua preocupação não é o "declínio" das elites ou da nação, mas as ameaças que o progresso técnico e econômico promovido pelo capitalismo faz pesar sobre a humanidade.

Por isso, compreender o cenário histórico e social de produção da arte e da cultura, e das consequentes poéticas e teorias, é importante para compreendermos que existem correspondências entre intelectuais condicionados pelas mesmas realidades, a despeito de não terem uma imediata relação e influência. É o que intitulo semovência, porque é como se essa produção intelectual e artística, enquanto coisa animada, se movesse por si própria, afastando-se de sua origem e intercambiando, em diálogo e comparativismo, com outras produções similares (verbo lat. semovére, 'apartar, arredar, afastar', derivando em semovência, pelo acréscimo de -ência, que funciona como sufixo em verbos, o que denota ação).

\section{AS NOÇÕES DE NEGRITUDE E CRIOULIZAÇÃO}

Entendendo que nesse processo semovente a produção de Bruno de Menezes não está apartada é que relacionarei a poética do autor paraense às concepções de negritude e crioulização. Mas, antes, vejamos os conceitos e suas origens. A Negritude foi um movimento literário afro-franco-caribenho iniciado na década de 1930, que teve por base a concepção de que há um vínculo cultural compartilhado por africanos negros e seus descendentes onde quer que eles estejam no mundo. Foi Aimé Césaire, em seu Cahier d'un retour au pays natal (1939) quem primeiro utilizou o termo negritude. $\mathrm{O}$ movimento enfatizou: a reivindicação, por parte do negro, da cultura africana tradicional, visando à afirmação e definição da própria identidade; o combate ao eurocentrismo advindo do colonialismo europeu e da educação ocidental prevalecente; a valorização da cultura negra no mundo, em razão de suas contribuições específicas do ponto de vista cultural e emocional, as quais o Ocidente, materialista e racionalista, nunca apreciou devidamente.

O jornal L'étudiant noir (1933) tem sido considerado o marco de nascimento do movimento. Estavam à frente Aimé Césaire (Martinica), Léon-Gontran Damas (Guiana Francesa) e Léopold Sédar Senghor (Senegal), naquele momento estudantes em Paris. Além de criticarem a arrogância do Ocidente e de proporem soluções socialistas para o problema dos povos explorados, esses jovens escritores formulavam uma nova visão do mundo para os negros, utilizando-se de um discurso contundente, como podemos observar no Manifesto literário, de Cesaire:

Detestáveis. Fundadores. Traiçoeiros. Feiticeiros. Feiticeiros, sobretudo. Pois nós queremos

todos os demônios.

Aqueles de ontem, os de hoje

Aqueles dos grilhões, aqueles do arado

Aqueles da interdição, da proibição, da fuga

E não temos intenção de esquecer aqueles dos navios negreiros...

Então cantamos

Cantamos as flores venenosas que desabrocham no prado raivoso; os céus de amor cortados

de embolia; as manhãs epilépticas; o branco abrasamento das areias abissais, as

descidas perdidas nas noites fulminadas por odores selvagens.

O que posso?

É preciso começar.

Começar o quê?

A única coisa no mundo que vale a pena começar.

O Fim do mundo, na verdade!

(CESAIRE, 1942,p. 7-12)

É perceptível, no Manifesto, o caráter formal e temático da Negritude: abolição das formas fixas, com a presença do poema em prosa; e a invocação da história subliminar do negro, com os interditados e fugitivos que agora tem voz; dos trabalhadores do eito, dos grilhões e do arado; dos feiticeiros, que somos todos. Toda essa convocação para um novo movimento, que instaure o começo, pautado no fim desse mundo colonial e opressor, essa é a única verdade!

Entretanto, a continuidade do movimento peca pelo ensimesmamento, ao considerar o essencialismo racial como única fonte de resistência e manutenção 
do movimento, o que é criticado por alguns pensadores da questão, a exemplo de René Depestre:

Longe de formar uma consciência contra as violências do subdesenvolvimento, a negritude dissolve seus negros e seus negro-africanos num essencialismo perfeitamente inofensivo para o sistema que subtrai aos homens e mulheres a sua identidade. Hoje os "negrólogos" da negritude a apresentam como uma concepção de mundo que, nas sociedades americanas ou africanas, seria exclusiva dos negros, independentemente da posição que eles ocupam na produção, na propriedade e na distribuição de bens materiais e espirituais. De fato, trata-se de uma weltanschanung (concepção de mundo, filosofia de vida, grifo meu) de origem anti-racista que, recuperada pelo neocolonialismo, tenta na sombra do movimento e reforçando-se em sofismas, manter os negros oprimidos distantes das determinações que devem fecundar suas lutas de libertação. A negritude, de movimento de contestação literária e artística que foi, no princípio, à ideologia de Estado em que se tornou, não é, entretanto, um fenômeno de geração espontânea. A negritude tem um passado: ela é, por certo, estreitamente tributária da história e das estruturas sociais formadas pelos escândalo americano do tráfico negreiro e o do regime da plantation (DESPESTRE, 1980, p. 84).

A preocupação com o destino do movimento se deve ao fato de que obliterou-se a participação do negro na formação das sociedades americanas, seja como o quilombola ou marronage; o escravo revoltado; os soldado das guerras de independência; o intelectual abolicionista e literato. Isso leva a crer em uma simples justaposição de raças/etnias, uma ao lado da outra, conservando-se intacta, o que reforça uma visão de multiculturalismo liberal, não de transculturação. Para Despestre, contrariamente o que houve foi uma censura a essa visão transculturadora na construção da América, o que o leva a afirmar que:

Há um determinismo sócio-histórico do hemisfério ocidental que, desde a "descoberta", em condições econômicas, culturais, religiosas, psicológicas, ecológicas, muito particulares, está dialeticamente influenciando a percepção dos diversos tipos sociais que, através dos antagonismos de classe e de "raça", modelaram as realidades nacionais. A criatividade histórica não foi o privilégio exclusivo de um grupo racial tomado isoladamente. A América dita unilateralmente latina ou anglosaxônica, proclamada arbitrariamente branca ou negra é, na verdade, uma criação social de múltiplas etnias: os aborígenes e as originárias de diversos países africanos e europeus. É o resultado etnohistórico de um doloroso processo de mestiçagem e de simbiose que, com o rigor de um fenômeno de nutrição, transformou ou mesmo transmudou os tipos sociais originais, as múltiplas substâncias e contribuições africanas, índias, européias, e produziu etnias e culturas absolutamente novas na história mundial das civilizações (idem, p. 86).

É em Glissant que podemos observar, com a construção de um conceito mais delimitado, o que Depestre acusa como uma falha na compreensão histórica e antropológica do papel do negro nas Américas. O conceito de crioulização surge com Édouard Glissant, a partir de um outro conceito, o Diverso. Para o autor, o mundo civilizacional ocidental impôs a alteridade do Mesmo ao universo transcendental e difratado do Diverso, mediante o processo colonizador. Esse processo de alteridade muitas vezes se ocultou através do humanismo universalizante que sublimou os particulares, os nacionais. Estabelecendo uma relação entre o Mesmo e o Diverso, nos diz Glissant:

O Diverso, que não é o caótico nem o estéril, significa o esforço do espírito humano em direção a uma relação transversal, sem transcendência universalista. O Diverso tem necessidade da presença dos povos, não mais como objeto a sublimar, mas como projeto a por em relação. O Mesmo requer o Ser, o Diverso estabelece a Relação. Como o Mesmo começou pela rapina expansionista no Ocidente, o Diverso nasceu através da violência política e armada dos povos. Como o Mesmo se eleva no êxtase dos indivíduos, o Diverso se expande pelo elo das comunidades. Como o Outro é a tentação do Mesmo, o Todo é a exigência do Diverso (GLISSANT, 1981, p. 192).

Apoiado na concepção de Diverso, Glissant institui o que considera a Poética da Diversidade como base para a compreensão das produções literárias nas Américas, quiçá no mundo, uma vez que essa poética se forja pela interpenetração cultural e linguística e se estabelece na Relação. Para se compreender essa poética deve-se compreender o processo colonizador. Para Glissant, as Américas se compõem a partir de três povos, formando respectivamente uma divisão triádica: a Meso-América, dos povos autóctones e testemunhas; a Euro-América, dos povos europeus colonizadores, que conservaram seus usos e costumes; e a NeoAmérica, a América da crioulização, ou seja, dos povos que foram despossuídos em sua diáspora, porque é no navio negreiro que as línguas nativas africanas desapareceram, ao se colocaram num mesmo porão indivíduos de culturas e línguas diferentes. Esses indivíduos tiveram que compor uma nova língua e cultura pelos rastros/resíduos de suas origens, mas de uma forma imprevisível, pois o que foi gerado deveria ser válido para todos aqueles despossuídos, e isso implicou em um acréscimo cotidiano e permanente nessa cultura e língua crioula, compósitas e nascidas do contato com o heterogêneo, com o Diverso. Em certa medida, segundo Glissant, esse fenômeno, que se inicia nos porões dos navios negreiros, termina por ser um fenômeno do mundo moderno, pois, para Glissant:

A crioulização que se dá na Neo-América e que se estende pelas outras Américas é a mesma que vem acontecendo no mundo inteiro (...). Isto é: hoje, as culturas do mundo colocadas em contato umas com as outras de maneira fulminante e absolutamente consciente transformam-se, permutando entre si, através de choques irremissíveis, de guerras impiedosas, mas também através de avanços de consciência e de esperança (GLISSANT, 2005, p. 18). 
E segundo o antilhano, esse contato tão osmótico determina que as culturas colocadas em relação se intervalorizem, sem que haja degradação ou depreciação de uma sobre outra nesse contato. Por isso a não aceitação de uma identidade única entre as nações americanas, antes devemos crer em Estados multinacionais e multiculturais, com identidades compósitas.

E como destacar, na poética de Bruno de Menezes, as características e propostas da negritude e da crioulização? Primeiramente, vale destacar que utilizarei três poemas do livro Batuque (1931), a saber "Mãe Preta", "Pai João" e "Toiá Verequête", a fim de ilustrar, em seus excertos, as características da negritude e da crioulização. Posteriormente, tecerei alguns comentários sobre a importância da obra do autor frente ao seu tempo e à sua inserção no cenário literário nacional e mundial.

Em relação à negritude, observamos que os poemas reivindicam a afirmação da cultura do negro como identidade do afro-amazônico seu descendente, uma vez faz alusão à Mãe Preta, a ama de leite dos filhos do Senhor, como "a mesma virgem de Loanda", que está na macumba "quando chega Ogum, no seu cavalo de vento". Estes versos concorrem para a valorização da cultura negra pelo mundo, uma vez que a Mãe Preta é a responsável pela vida do Sinhô e da Sinhá, por isso devemos valorizá-la, pedindo sua benção: "Abençoa-nos, pois, aqueles que não se envergonham de Ti, / que sugamos com avidez teus seios fartos / - bebendo a vida! - / que nos honramos com teu amor! / - Tua benção, Mãe Preta!".

Ao lembrarmos do Manifesto Literário, de Cesaire, por certo podemos destacar passagens do poema "Pai João". Ao clamar por todos os demônios, o que se quer invocar não são os espíritos malignos, mas aqueles que foram tratados pejorativamente na sociedade e consequentemente marginalizados na História: " $E$ rabo-de-arraia, cabeçada na polícia, / xadrez, desordens, furdunço no cortiço"; mas, de outro modo, ajudaram a compor a história dos poderosos e vencedores: "E a guerra do Paraguai! Recrutamento! / Gurjão! Osório! Duque de Caxias! / Itororó! Tuiuti! Laguna! / E não sabia nem o que era monarquia!”. Menezes traz para sua poética aqueles que foram os vencidos, não porque abandonaram a batalha, mas porque nunca foram reconhecidos como os heróis de fato, como Pai João, só lembrado como o capoeira e navalhista criminoso, perseguido pela polícia, na história oficial. Só que Menezes faz o contra-pelo.

Com isso, Bruno de Menezes vai além do ensimesmamento em que desaguou a negritude, em certo momento, porque dá visibilidade aos cenários e personagens periféricos em sua poesia. Com isso contribui para a marronage na cultura, só para lembrar as comunidades livres de negros fugitivos em que a múltipla origem dos indivíduos levou à criação de condições de vida comunitária em que o que prevaleceu foi a diversidade. Assim Menezes configura sua poética como a diversidade de cenários e indivíduos, que lembram o Jurunas de sua origem, os largos de igreja, as festas religiosas, os capoeiras, as mães de santo, enfim, o que evita que sua poesia tenha um caráter essencialista no tocante a encontrar uma pureza africanista em seus versos.

É nesse momento em que a poética de Menezes se afina com a crioulização, ou seja, pela presença do Diverso. Observemos em "Mãe Preta" que no mesmo processo histórico de formação da sociedade brasileira estão as narrativas orais do Saci e do murucututu, em acalentos aos filhos do Sinhô, mas também encontramos a narrativa religiosa de São Tiago. E o que é mais relevante: não são histórias meramente justapostas, como a dizer que uma é superior a outra. Não, são narrativas que se imbricam, interrelacionam, pois a estrada de São Tiago nasce do leite forte do seio de Mãe Preta, assim como o Cruzeiro do Sul, símbolo maior do civismo nacional: "A tua seiva maravilhosa / sempre transfundiu o ardor cívico, o talento vivo, / o arrojo máximo!". Também, no mesmo poema, clama-se pela presença de figuras máximas da história do Brasil, a exemplo de Luiz Gama. Filho nato de fidalgo português com africana da nação nagô, sua história está intimamente ligada aos momentos limiares de formação do Brasil moderno, desde a condição de escravo do eito e escravo doméstico até ser advogado e jornalista ligado à causa abolicionista e republicana. É um exemplo de invocar-se para a história da nação quem sempre esteve obliterado por sua condição social e racial, com isso Menezes valoriza o Outro, colocando-o em pé de igualdade com quem sempre esteve no poder. E constrói uma poética e uma nova história, pelos resíduos deixados por aqueles que foram heróis, não meros adjuvantes.

Para finalizar, esses breves comentários acerca de seus poemas, é interessante a leitura do poema "Toiá Verequête". Fica latente o que Glissant considera como a necessidade do Diverso: “o Todo é exigência do Diverso" e "o Diverso estabelece Relação"; como? O poema em exegese apresenta uma sessão de umbanda no terreiro de Mãe Ambrosina, quando "baixa" a entidade Toiá Verequête. Em meio aos cantos, às fumaças do Bahia, aos rodopios, Verequête nada mais é do que São Benedito, o Santo dos pretos. Ora, este é um santo do catolicismo, mas que frequenta tranquilamente as rodas da macumba, como se fosse a dupla manifestação da mesma entidade: Verequête católico, São Benedito umbandista? Não, um em dois, dois em um, variações sobre o mesmo tema, ou o Diverso em relação, sem deixar de ser uma parte que completa o Todo. 


\section{CONCLUSÕES}

À guisa de conclusão, mas sem querer concluir, pois há muito o que anunciar, quero dizer que a importância de Bruno de Menezes está posta pelo seu trabalho, mas como há necessidade "acadêmica" de dar visibilidade, aqui elenco algumas questões. Para seu tempo, literariamente falando, Bruno significou um marco, pois a revista em que esteve à frente, a Belém nova (quatro volumes, que circularam de 1923 a 1929) foi responsável, depois da Mina Literária (associação de escritores que funcionou de 1895 a 1899), pela propagação da literatura em Belém, estimulando a formação de uma intelectualidade que pensasse a partir do local. Com diferencial que a Belém nova foi o veículo de divulgação do modernismo brasileiro quase que em tempo real; não é a toa que Belém é considerada a terceira capital brasileira a aderir a esse movimento literário. Portanto, Bruno é pioneiro do modernismo na Amazônia. Isso irá se refletir, evidentemente, na sua produção poética, seja em versos ou em prosa, além do interesse pelo folclore.

No entanto, não houve continuidade entre os movimentos literários na cidade de Belém, o que impede, na visão de Antonio Candido, que construamos uma visão de literatura local como sistema, ou seja, tivemos manifestações literárias, não propriamente literatura:

Quando a atividade dos escritores de um dado período se integra em tal sistema, ocorre outro elemento decisivo: a formação da continuidade literária, - espécie de transmissão de tocha entre corredores, que assegura no tempo o movimento conjunto, definindo os lineamentos do todo. É uma tradição no sentido completo do termo (...) (CANDIDO, 1993, p. 24).

O que quero dizer é que a geração posterior ao que intitulei geração de 20 ou do Peixe Frito - capitaneada por Bruno de Menezes e Dalcídio Jurandir não foi reconhecida de imediato pela geração de 40, ou Grupo dos Novos, pelo menos de imediato. Por quê? Somente em 1942, com o grito "Morra a Academia!", de Max Martins ${ }^{4}$, é que esse grupo, posteriormente tão importante para a vida intelectual de Belém, em que figurava Bendito Nunes, renomado crítico literário de Clarice Lispector e filósofo, entre outros, se converteu ao modernismo, mas antes assumindo-se parnasiano. E isso por obra e graça do Prof. Francisco Paulo Mendes, que em suas aulas, no Colégio Nazaré, trouxe a novidade, quase vinte anos depois da pedra fundamental da Semana de Arte Moderna. Por que a geração

Max da Rocha Martins (Belém, 1926 - Belém, 2008) foi funcionário público e poeta paraense, notabilizado por uma produção poética marcada pela relação entre palavra e imagem. Teve alguns de seus poemas traduzidos para o espanhol, o inglês e o francês. Em 1992 lançou a antologia Não para consolar - poesia completa, pela Editora Cejup. de 40 não teve acesso ao modernismo aqui mesmo, uma vez que graças a Bruno fomos a terceira capital a aderir ao movimento? Faltam estudos que justifiquem essa cisão entre 1920 e 1940 na literatura local, mas tenho alguns indicadores que podem encaminhar uma possível resposta: a distância etária entre as gerações e a distância social, entre centro e periferia. Vale lembrar que Bruno e Dalcídio eram mais velhos que a geração seguinte, esta em média com 15 anos, e que os dois autores escreveram a partir da periferia (social e urbana), daí a dificuldade em fazer circular suas ideias e obras. A geração de 40 está mais no "centro" da produção intelectual e artística de Belém, estudando em "bons" colégios e tendo acesso ao que se produzia de mais ulterior na cena literária e cultural do mundo, inclusive se reunindo em torno de um jornal de grande circulação à época, $A$ Folha do Norte, de propriedade do avô do escritor Haroldo Maranhão, o jornalista Paulo Maranhão. Também uma das razões pudesse ser a partida para outras plagas, logo cedo, de alguns escritores, como Dalcídio Jurandir, que ainda nos anos quarenta foi morar no Rio de Janeiro. Mas o que dizer de Bruno de Menezes, que permaneceu em Belém?

Uma explicação assenta-se na noção de campo de Pierre Bourdieu. Para o teórico francês esta noção

É uma idéia extremamente simples, cuja função negativa é bastante evidente. Digo que para compreender uma produção cultural (literatura, ciência etc.) não basta referir-se ao conteúdo textual dessa produção, tampouco referir-se ao contexto social contentando-se em estabelecer uma relação direta entre texto e contexto (...). Minha hipótese consiste em supor que, entre esses dois pólos, muito distanciados, entre os quais se supõe, um pouco imprudentemente, que a ligação possa se fazer, existe um universo intermediário que chamo o campo literário, artístico, jurídico ou científico, isto é, o universo no qual estão inseridos os agentes e as instituições que produzem, reproduzem e difundem a arte, a literatura ou a ciência (BOURDIEU, 2004: 20).

Como relacionar a teoria de Bourdieu com as condições sociais e históricas de produção em Bruno de Menezes? Creio que a origem mais popular de Menezes tenha circunscrito sua produção a um caráter mais "folclorizante", e esta tarja no campo literário ainda soa como uma produção de menor estirpe. Aceitar a modernidade literária pode parecer uma atitude meramente exótica, ao estilo de um estrangeiro que observa com complacência a produção inferiorizada, pela total incompreensão da natureza e função da produção circunscrita a um modelo estético outro. Menezes parece ter sido assim observado em terras paroaras, pois o campo literário reinante, a partir de 1940, se dedica ao hermetismo poético, não à poesia das ruas e dos marginalizados, o que está impresso em Batuque. Esse universo intermediário e legitimador dos anos 40 distanciou-se da geração de 20, 
ou melhor, parece não ter se dado conta de um sentido de sistema entre esses movimentos literários, e, assim, todo sentido de continuidade na constituição de uma literatura degringolou: a cultura virou boemia, como diria Jurandir no prefácio de Menezes à obra de Jacques Flores, citado anteriormente, ou melhor, o passado isolou-se no passado, pois a obra de Menezes não estava no campo de poder, que, para Bourdieu, "é o espaço das relações de força entre agentes ou instituições que têm em comum possuir o capital necessário para ocupar posições dominantes nos diferentes campos (econômico ou cultural, especialmente)" (BOURDIEU, 1996: 244). Vale lembrar que Menezes não viveu, efetivamente, de sua produção poética, sendo funcionário público até o fim de sua vida, o que reflete o grau de reconhecimento de sua produção literária em seu tempo; não se percebeu a importancia de sua obra como marco da modernidade e do modernismo no Brasil, mesmo porque o que se convencionou intitular de literatura negra, marcada pela negritude e crioulização, só terá foro no campo literário com a construção, na teoria literária, de conceitos como hibridismo e multiculturalismo, questões de fins do século XX. Mas nunca é tarde para o reconhecimento, por isso que este artigo se insere como indicativo para esse caminho, qual seja de valorar a obra poética de Bruno de Menezes em seus primordios.

De todo modo, decorrido tanto tempo, podemos hoje, com mais clareza, observar a importância de Bruno - daí sua ligação não com seu tempo e espaço, mas com outros tempos e outros espaços. Por isso, entender sua produção poética em uma corrente maior, mundial, em que entender o significado de negritude e crioulização é tão importante para entender a importância de sua obra: podemos crê-la como além de seu tempo, na dinâmica mundo da produção literária e mundial, corroborando Cesaire, Depestre e Glissant. Visto dessa maneira, Bruno não merece apenas estar no cânone da literatura brasileira, mas da literatura mundial. Bruno antecipa a negritude a partir do local, como vimos, pois o próprio termo só surge em 1939, e o grupo que o levou a guisa (Cesaire, Senghor e Damas) só se formou em 1933; Batuque é publicado em 1931! E o que se dirá da teoria da crioulização, pois, como pudemos compreender, os poemas estudados corroboram a teoria de Glissant, que só irá aparecer, como teoria do Diverso, em 1981. Portanto, Bruno de Menezes merece sim o reconhecimento da crítica literária nacional e mundial, mas, talvez como ele, e irmanado a ele, acredito que o melhor reconhecimento é o do público do dia a dia, dos bumbás, das baiúcas, dos terreiros, dos largos de igreja. E isso ele soube ter e fazer como ninguém. Sua benção, Bruno de Menezes!

\section{REFERÊNCIAS}

BASTIDE, R. Poetas do Brasil. São Paulo: Edusp; Duas Cidades, 1997.

BOURDIEU, Pierre. As regras da arte. São Paulo: Companhia das Letras, 1996.

BOURDIEU, Pierre. Os usos sociais da ciência; por uma sociologia clínica do campo científico. São Paulo: Ed. da Unesp, 2004.

CANDIDO, A. Formação da literatura brasileira. v.1. Belo Horizonte; Rio de Janeiro: Itatiaia, 1993.

CESAIRE, Aimé. En guise de manifeste littéraire. Tropique, Fort-de-France n.5 p. 7-12, avril, 1942. Tradução de Giselda Lima Andrade. Disponível em: <http:// www.ufrgs.br/cdrom/cesaire/cesaire.pdf>. Acesso em: 17 nov. 2010.

COELHO, M. O. O grupo dos novos. Belém: Edufpa; Unamaz, 2005.

DEPESTRE, R. Bonjour et adieu à la négritude. Tradução de Maria Nazareth Fonseca. Paris: Robert Laffont, 1980. Disponível em: <http://www.ufrgs.br/ cdrom/depestre/depestre.pdf>. Acesso em: 17 nov. 2010.

GLISSANT, E. Le discours antillais. Tradução Normélia Parise. Paris: Seuils, 1981. Disponível em: <http://www.ufrgs.br/cdrom/glissant/>. Acesso em: 17 nov. 2010.

Introdução a uma poética da diversidade. Juiz de Fora: EDUFJF, 2005.

LÖWY, M. A filosofia da história em Walter Benjamin. Disponível em: <http:// www.scielo.br/scielo.php?>. Acesso em: 1 set. 2010.

MENEZES, B de. Obras completas. v. 2. Belém: SECULT: Conselho Estadual de Cultura, 1993. (Série Lendo o Pará, 14)

Batuque. Belém: [s.n], 2005.

RODRIGUES, C. I. Vem do bairro do Jurunas; sociabilidade e construção de identidades em espaço urbano. Belém: NAEA, 2008.

Texto submetido à Revista em 21.1.2010

Aceito para publicação em 5.10.2010 
